\title{
A study on physico-chemical parameters of Dah lake water, District-Ballia (U.P.), India
}

\author{
Rajnish K umar Sharma*, Devendra K umar Soni ${ }^{1}$ and Nirupma A grawal
}

Department of Zoology, University of Lucknow, Lucknow-226007, INDIA

${ }^{1}$ Central Pollution Control Board, Zonal Office, Lucknow-226010, INDIA

*Corresponding author. E-mail: rajnish.enviro.80@gmail.com

Received: J une 8, 2012; Revised received: J uly 25, 2012; Accepted: September 28, 2012

\begin{abstract}
The back water of river Saryu is a prime source of water for Dah Lake, located in Ballia district, have been studied to project the pristinety of water with respect to different pollution sensitive parameters i.e. organic pollutantsBOD, DO, COD, Inorganic pollutants - Electrical Conductivity, Turbidity, $\mathrm{pH}$, total alkalinity, Chloride, Total hardness etc. The $\mathrm{pH}(7.68)$, total alkalinity (180.5 mg/l), Chloride (133.12 mg/l), Total hardness(139.83 mg/l), Calcium (60.26 $\mathrm{mg} / \mathrm{l})$ and Magnesium hardness $(19.38 \mathrm{mg} / \mathrm{l})$ were found well within the prescribed standard for drinking water (BIS 10500:1991) during the study period i.e. April 2006- March 2008. The study inferred that the water quality of Dah Lake is still free from the any kind of pollutants, must be due to its higher assimilative capacity. It also indicates the higher potential for pisiculture and drinking water sources (after disinfection) for the nearby villages which may ultimately improve the economic condition of the surrounding habitation.
\end{abstract}

Keywords:Assimilative capacity, Dah lake, Dissolved oxygen, Physico-chemical characters, Water quality

\section{INTRODUCTION}

Water is one of the most important natural resource available to mankind. Knowing the importance of water for sustenance of life, the need for conservation of water bodies especially the fresh water bodies is being realized everywhere in the world. Lakes, rivers and reservoirs are most important water resources and used for several purposes. Physicochemical Analysis on Dah Lake was aimed to assess the deterioration of water quality. A number of authors have studied the physical and chemical characteristics of some Indian water bodies i.e. Rawat, 2002; Arjariya, 2003; Sharma and Sarang, 2004; Tiwari and Chauhan, 2006; Tamot and Sharma, 2006; Vyas et al., 2006; Kumari et al., 2007; Khare and Jadhav, 2008; Srivastava et al., 2009; Patra et al., 2010; Puri et al., 2010; Koli and Ranga, 2011; Gupta et al., 2011; Sharma et al., 2011; Parameswara et al., 2012; Kulkarni and Tapase, 2012; Khan et al., 2012; Naik et al., 2012. The Characteristics feature of Eastern Uttar Pradesh is the presence of numerous lakes, ponds and reservoir which offer immense scope for fish culture practices. In the district Ballia itself, there are three large lakes viz.; Surha, Reoti and Dah Lake which cover an area of about 600 hectors of perennial Lake. Besides, there are nearly 476 small tanks and water depressions with a total area of 458 hectares. River Ganga, Gharaghra and Tons with 29 $\mathrm{km}$. of length pass through this district. Such a vast area water is presently in a state of deletion and neglect and warrants immediate attention of the fishermen if exploitation on scientific basis.

Dah Lake is an ox-bow lake formed by the former channels of the river Gaghara the two ends having been silted up subsequently to the adoption of a new course of the river. The lake, extending between the parallels $25^{0} 55^{\prime} 34.56^{\prime \prime} \mathrm{N}$ latitude $84^{\circ} 12^{\prime} 12.35^{\prime \prime} \mathrm{E}$ longitude cover an area of 117.37 hectors of perennial water. The lake, with a more or less steeply margin on the outer side ad a little margin slop on the inner side (forming a narrow strip of littoral region) has a shallow basin and looks like a river bed. During monsoon period, it swells to inundate though a small marginal lake but became confluent with several large low lying areas and also establishes continuity with the river Ghaghara. The Lake receives water through two streamlets via Bhedia nala and Nara. During rainy season both these streamlets collected rain water from far distant areas and discharge into the lake. However, during late winter and summer, they completely dry up leaving a few discontinuous water patch. The objective of the study was to monitor the water quality of the lake with respect to its suitability for drinking water and pisciculture potential.

\section{MATERIALS AND METHODS}

Monitoring of the Lake carried out twice in month during April, 2006 to March, 2008 from 8 pre-identify locations following the standard sampling procedure (NEERI, 1991). The samples were transported to the laboratory and analysis for the different parameters viz Electrical conductivity, Turbidity, pH, BOD, DO, COD, total ISSN : 0974-9411 (Print), 2231-5209 (Online) All Rights Reserved @ Applied and Natural Science Foundation www.ansfoundation.org 
alkalinity, Chloride, Total hardness following standard procedure (APHA, 2005).

\section{RESULTS AND DISCUSSION}

The physicochemical parameters of the Dah Lake have been given in the table 1 . The mechanism of controlling the chemistry of surface water has been discussed by the Gibbs (1970). According to him there are three basic origins for chemical load of dissolved salts in surface water, atmospheric precipitation, rock weathering and crystallization. The temperature has greater role in the dynamic of aquatic ecosystem. In the present study both the atmospheric and water temperature fluctuated from $31.0^{\circ} \mathrm{C}$ to $34.6^{\circ} \mathrm{C}$ and $28.3^{\circ} \mathrm{C}$ to $30.0^{\circ} \mathrm{C}$ respectively at different studied sites. The variation in water temperature may be due to monitoring time and fluctuation in the weather conditions of the area (Jayaraman et al., 2003). Temperature dictates the behavioral characteristics of organisms, solubility of gases and salts in water bodies. No other factor has so much influence as temperature (Welch, 1952). The Electrical conductivity (E. C.) ranged from 17.8 to $37.7 \mu \mathrm{mho} / \mathrm{cm}$. The maximum values (37.7) were recorded in spring and minimum (17.8) in winter. The increase of E. C. is a indication of the enrichment of the ions in water bodies and may be due to natural sources or by the anthropogenic sources. Since no significant manmade contributor was notices during the study which indicated that only natural sources imparting the variation that too not significant. Similar kind of observation has been recorded by Rajyalakshmi et al. (1988) i.e. specific conductivity varied between 8.70 to $8.90 \mathrm{~m} \mathrm{mhos} / \mathrm{cm}$ in the ponds of Chilka fringe area indicating the high salt contents. The Turbidity of the lake water did not fluctuated significantly and remained under the prescribed limit i.e. 8.78 against the prescribed highest desirable of $5 \mathrm{NTU}$ and maximum permissible limit 25.0 NTU. The $\mathrm{pH}$ of the Dah lake at most of the studied sites was more than 7.5 except at 2, 4 and 7 location. The $\mathrm{pH}$ and alkalinity goes hand to hand and are inversely proportional to water and air temperature. These are positively correlated to each other (Ranjan et al., 2007). As per the water classification (CPCB-DBU-2008) on the basis of $\mathrm{pH}$ water falls under the " $\mathrm{A}$ " class and is fit for drinking purpose provided all other parameters also fall under the class. Rajyalakshmi et al. (1988) recorded higher values of $\mathrm{pH}$ ranging from 8.3 to 8.9 in the ponds of Chilka fringe area. Chattopadhyay et al. (1988) reported $\mathrm{pH}$ between 7.2 to 8.4 in the coastal saline water ponds. Wetzel (1975) reported that the value of $\mathrm{pH}$ ranges from 8 to 9 in Indian waters. The $\mathrm{pH}$ of pond water was influenced by the monsoon, temperature and soil conditions. Dissolved oxygen (DO) concentration in the water bodies is a kind of indication of general health of lake. During this study the DO level was found more

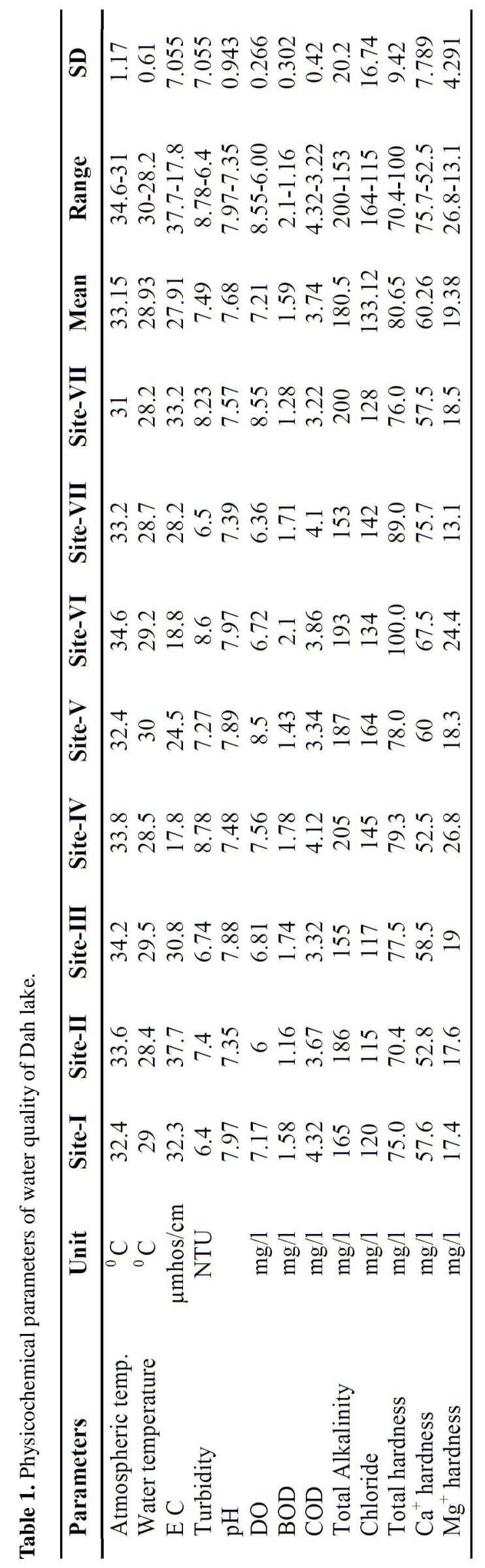


than $6 \mathrm{mg} / \mathrm{l}$ which showed a very good health of the lake i. e. under the "A class of water as per the Water classification. DO level in the water bodies is temperature dependent. It also depletes as the organic load increases. Similar kind of study is also reported by Rajyalakshmi et al. (1988) which indicated DO concentration ranging from 3.40 to $6.52 \mathrm{mg} .1-1$ in the brackish water ponds of Chilka fringe area. Thampy et al. (1988) observed that DO concentration fluctuated between 1.4 to $8.2 \mathrm{mg} / \mathrm{l}$ in the saline ponds at Cochin. Devaraj (1988) noted concentration of DO from 3.7 to $8.2 \mathrm{mg} / \mathrm{l}$. In the present study, the dissolved oxygen ranged from to 6.0 to 8.0 mg.l-1 during the first year of study while during second year it ranged from 6.1 to $8.4 \mathrm{mg} / \mathrm{l}$.

Biochemical Oxygen Demand (BOD) is the key parameter which indicates the organic load of the water body or aquatic ecosystem. BOD in the study area varied from 1.16 to $2.1 \mathrm{mg} / \mathrm{l}$ during study period which indicates that the existing ecosystem do not have any significant source of organic pollution and existing system is capable of assimilating the organic load in case any pollution occurred. Similar finding has been projected by the Paramesher et al. (2012) at Kunigal lake in India. Chemical Oxygen Demand (COD) is a measure of oxygen equivalent to the requirement of oxidizing organic matter contents by a strong chemical agent. The COD test is helpful in assessing the toxic conditions and the presence of biologically resistant organic substances. The COD concentration fluctuated between $3.22 \mathrm{mg} / \mathrm{lit}-4.32 \mathrm{mg} / \mathrm{l}$. The variation is not much. The COD data infer that no chemically active substances are entering in the aquatic ecosystem which may alter the primary productivity of the system. The alkalinity of water is its capacity to neutralize acids; it ranged from the $153 \mathrm{mg} / \mathrm{l}$ to $200 \mathrm{mg} /$ 1 which is well within the desirable level of alkalinity for drinking water assigned by BIS (1991). Rajyalakshmi et al. (1988) and Gupta et al. (2008) and Parameswara et al. (2012) reported similar observation in the Kunigal Lake in Tumkur district, Karnataka of the India. The Chlorides occurs naturally in all types of water and waste water forming a major inorganic anion. In the present study the values ranged from a minimum of 115 and maximum. $164 \mathrm{mg} / \mathrm{l}$. Similar findings are projected by the Singh et at., (2011) for Kodaikanal Lake (Dindugal District), in India. Calcium and Magnesium were the dominant cations in the lotic aquatic ecosystem (Buckney, 1980). Calcium concentration was minimum of $52.5 \mathrm{mg} / \mathrm{l}$ to the maximum of $75.7 \mathrm{mg} / \mathrm{l}$ and the magnesium concentration of the present study is ranged from $13.1 \mathrm{mg} / \mathrm{l}$ to $26.8 \mathrm{mg} / \mathrm{l}$ and present observation is in line with the reports of Kumar et al. (2006).

\section{Conclusion}

The present study concluded that the pristinety of Dah Lake is maintained with respect to the studied physicochemical parameters and the water resources may be utilized for the propagation of the pisciculture at commercial scale which may uplift the economic status of the nearby habitation apart from the irrigation and drinking water source (after disinfection).

\section{ACKNOWLEDGEMENTS}

The authors extend thanks to the authorities for extending the laboratory facilities at Uttar Pradesh State Pollution Control Board, Lucknow during study.

\section{REFERENCES}

American Public Health Association (2005). Standard methods for the examination of water and waste water (12th edn.). Washington, DC: American Public Health Association.

Arjariya, A. (2003). Physic-chemical profile and plankton diversity of Ranitallake, Chhatarpur, M.P., Nature Environment and Pollution Technology, 2: 327-328.

Buckney, R T. (1980). Chemistry of Australian waters: the basic pattern with comments on some ecological implications. In Williams, W. D. (Ed.), An Ecological Basis for Waler Resources Management, Aust. Nat. Univ. Press, Canberra.

BSI (1991). Indian standard specification for drinking water, New Delhi.

CPCB (2008).Guideline for water quality management, New Delhi, CPCB/MINARS/27/2007-2008: 1-35.

Devaraj, K.V., Mahadeova, H.S. and Fazal, A.A. (1988). Hydrology of the Hemavathy reservoir., Proc. First Indian Fish. Forum, M angalore: 323-327.

Gibbs, R. J. (1970). Mechanisms Controlling World Water Chemistry, Science, 170: 1088-1090.

Gupta, P. Agarwal, S. and Gupta, I. (2011). Assessment of Physico-chemical parameters of various lakes of Jaipur, Rajasthan, India. Indian J ournal of F undamental and A pplied Life Sciences, 1: 246-248.

Gupta, P.K. Nagdali, S.S. Tewari, P. and Singh, N. (2008). Water chemistry of a national lake of India: Lake Nainital, Uttarakhand, Sengupta, M. And Dalwani, R. (Editors), 2008, Proceeeding Of Taal 2007: The 12th World Lake Conference, : 209-216.

Jayaraman, P.R., Ganga D.T. and Vasudena Nayar, T. (2003). Water quality studies on Karamana River, Thiruvananthapuram district South Kerela, India. Pollution Research, 22: 89-100.

Khan, R.M., Jadhav, M.J. and Ustad, I.R. (2012). physicochemical analysis of Triveni lake water of Amravati District in (Ms) India, Bioscience D iscover y, 3: 64-66.

Khare, K. C. and Jadhav, M. S. (2008). Water quality assessment of Katraj lake, Pune (Maharashtra, India): Sengupta, M. and Dalwani, R. (Editors), 2008, Proceeeding of Taal 2007: the 12th world lake conference,: 292-299.

Koli, V.K. and Ranga, M.M. (2011). Physicochemical status and primary productivity of Ana Sagar lake, Ajmer (Rajasthan), India. Universal J ournal of Environmental Research and Technology, 1: 286-292.

Kulkarni, S.V. and Tapase, B.S. (2012). Physico-chemical 
parameters and water quality index of Gandhisagar lake of Umrer in Nagpur district. Indian Streams Research J ournal, 1: 1-4.

Kumar DS, Sukumar NC, Jana C and Philipose MT (2006). Study on physico-chemical characteristics of Thunga River. Phykos, 32: $27-39$.

Kumari, S., Sahu, K., Mehta, A., Shukla, S. (2007). Assessment of physico-chemical parameters of Sagar lake, India, Asian J ournal of Bio Science, 2: 76-78.

Naik, T.P., Ajayan, K.V. and Lokesh, G.H. (2012). Physicochemical characteristics of Kunigal lake in Tumkur district, Karnataka, India. Int. J . Chem. Sci., 10: 655-663.

NEERI (1991). Manual on water and waste water analysis. National Environmental Engineering Research Institute, Nagpur.

Parameswara, T.N, Ajayan, K.V. and Lokesh, G.H. (2012). Physcio-chemical characteristics of Kunigal lake in Tumkur Disctrict, Karantaka, India. Int. J. Chem. Sci., 10: 655663.

Patra, A.P., Patra, J.K., Mahapatra, N.K. Das, S. and G.C. Swain (2010). Seasonal variation in physicochemical parameters of Chilika lake after opening of new mouth near Gabakunda, Orissa, India. World J ournal of Fish and Marine Sciences, 2: 109-117.

Puri, P.J., Yenkie, M.K.N., Battalwar, D.G., Gandhare, N.V. and Dhanorkar, D.B. (2010) Study and interpretation of physico-chemical characteristic of lake water quality in Nagpur city (India). Rasayan J. C hem., 3: 800-810.

Rajyalakshmi, T., Mohanty, A.N., Ravichandran, P. and Pillai, S.M. (1988). The soil and water characteristics of confined brackish water ponds of Chilka lake fringe area. Proc. First Indian Fisheries F orum, Mangalore.: 125-128 .

Ranjan, C.P., Chinmoy, C. and Raziuddin, M. (2007). Impact of human activity on water quality of lentic water body in Asansol. Nat. Environ. Pollut. Technol., 5: 59-62.
Rawat, M. S. (2002). Diurnal variation is pjysico-chemical profile and fish fauna of Saudi Gad., G eobios., 29:151-153.

Sharma, L.L. and Sarang, S. (2004). Physico-chemical limnology and productivity of Jaisamand lake, Udaipur (Rajasthan). Pollution Research, 23: 87-92.

Sharma, S., Yadav, R.K., Saini, Y. and Sharma, S. (2011). Water quality status of Pushkar lake as a primary data for sustainable development. South Asian J ournal of Tourism and Heritage, 4: 184-192.

Singh, R.P. and Balasing, G.S.B. (2011).Limnological studies of Kodaikanal lake (Dindugal District) in special reference to phytoplankton diversity. Ind. J. Fund. \& Applied Life Sci., 1: 112-118.

Srivastava, N., Harit, G. and Srivastava, R. (2009). A study of physico-chemical characteristics of lakes around Jaipur, India, J. Enviro. Biol., 30: 889-894.

Tamot, S. and Sharma, P. (2006): Physico-chemical status of upper lake (Bhopal, India) water quality with special reference to phosphate and nitrate concentration and their impact on lake ecosystem. Asian J . Exp. Sci., 20: 151-158.

Thampy, D.M., Jose, S. Mohan, M.V. and M.S.S. Koya (1988). Short-term biculture of tiger prawn, Penaeus monodon (Fabricius) and milkfish, Chanos chanos (Foskel) in a low saline ponds. Proc. First Indian Fish. Soc. M angalore, :139141.

Tiwari, A. and Chauhan, S.V.S. (2006). Seasonal phytoplankton diversity of Kitham lake, Agra. J . Environ. Biol., 27: 35-38.

Vyas, A. Mishra, D.D., Bajapai, A., Dixit, S. and Verma, N. (2006). Environment impact of idol immersion activity lakes of Bhopal, India Asian J. Exp. Sci., 20: 289-296.

Welch, P.S. (1952). Limnological methods. New York: McGraw-Hill.

Wetzel, R.G. (1975). Limnology, W. B. Saunders Co., Philadelphia, USA, 74. 